\title{
Biochemical Studies of Lethal Processes in Aerosols of Escherichia coli
}

\author{
By J. D. ANDERSON \\ Microbiological Research Establishment, Porton, Salisbury, Wiltshire
}

(Received 3 March 1966)

\begin{abstract}
SUMMARY
The effects of holding time and relative humidity on the survival of populations recovered from aerosols of Escherichia coli strain B was examined. $\beta$-Galactosidase was chosen as a convenient model of a bacterial protein in this organism. Populations recovered from aerosols of $\boldsymbol{E}$. coli strain $\mathrm{B}$ were shown: (i) to have suffered no detectable damage to $\beta$ galactosidase; (ii) to have suffered a temporary and severe loss of ability to synthesize $\beta$-galactosidase. The significance of these results in identifying lethal mechanisms in bacterial aerosols is discussed. For these studies a method was developed for the determination of total bacterial numbers recovered from aerosols by labelling the organisms directly with $\left[{ }^{14} \mathrm{C}\right]$. Bacillus globigii was shown to be unsuitable as a tracer for the determination of total numbers in biological aerosols.
\end{abstract}

\section{INTRODUCTION}

The propagation of many plant and animal diseases depends on the transfer of the causative organisms in an aerosol. Although many pathogenic and non-pathogenic organisms are known to be less stable in aerosols than in aqueous suspensions, comparatively little is known of processes in aerosols which lead to death or loss of infectivity or in what way these processes resemble similar phenomena resulting from stresses such as starvation, drying, exposure to radiation or ageing. Escherichia coli was chosen as a convenient simulant of the pathogenic bacteria, but since this organism is not normally pathogenic only changes in viability could be studied. Changes in the viability of this model organism can be taken only as an indication of possible changes of infectivity of a pathogen since some pathogenic bacteria recovered from aerosols are viable in vitro yet not infective in vivo (e.g. evidence summarized by Goodlow \& Leonard, 1961).

Stresses which may act on bacteria responsible for the spread of natural infections include radiation, relative humidity, temperature and composition of the atmosphere, and physical forces involved in the generation and recovery of organisms from the aerosol. The viability of recovered aerosolized organisms may also be markedly influenced by the presence of extraneous material such as spent culture fluid or tissue exudates in fluids used in the generation and recovery of the aerosols. The present communication is primarily concerned with biochemical processes in an aerosol generated from a washed suspension of Escherichia coli strain B, maintained at controlled temperature and humidity in the dark in a suitable apparatus. Changes in the viability and certain biochemical properties of the bacterial populations recovered from aerosols were determined and related to changes in the relative 
humidity and age of aerosols in an attempt to locate the actual site of damage in the organism.

\section{METHODS}

Organisms. Escherichia coli strain B was grown from freeze-dried cultures on tryptic meat agar at $37^{\circ}$ for $18 \mathrm{hr}$. A typical colony was selected, grown in meat broth $\left(37^{\circ}, 18 \mathrm{hr}\right)$ and stored at $4^{\circ}$. This culture was used as a stock inoculum for 4 months, then discarded. Bacillus globigii (B. subtilis var niger) spores were obtained from several sources; a laboratory strain kindly provided by Mr F. C. Belton was used for most of the work.

Media. The tryptone medium (H. E. Wade, private communication) contained Oxoid tryptone, $2 \%$; sodium chloride, $0.3 \%$; dipotassium hydrogen phosphate, $0.005 \mathrm{M}$; ferric citrate $0.001 \mathrm{M}$; calcium chloride, $0.001 \mathrm{M}$; magnesium sulphate, $0.004 \mathrm{M}$; adjusted to $\mathrm{pH} \mathbf{7 \cdot 2}$ with sulphuric acid. The agar medium for general use contained: 'Oxoid' tryptone, $1.0 \%$; agar, $1.5 \%$; glucose, $1.0 \%$; sodium chloride, $0.5 \%$. An agar medium used only for the growth of pure cultures of Bacillus globigii contained: Lab Lemco, $0.2 \%$; peptone, $0.5 \%$; sodium chloride, $0.5 \%$; glucose, $0.5 \%$; agar, $3 \%$.

Phosphate buffer alginate. Potassium dihydrogen phosphate, $\mathbf{0 \cdot 4 5} \%$; ammonium sulphate, $0.05 \%$; ammonium chloride, $0.05 \%$; sodium alginate ('Manucol SS/LH' by Alginate Industries Ltd., London W.C. 2) $\mathbf{0 \cdot 2 5} \%$; sodium hydroxide to $\mathrm{pH} \mathbf{7 \cdot 2}$, approximately $0.1 \%$. This medium was used in the collection of bacteria and for all serial dilutions. Alginate was incorporated to minimize losses of organisms by physical processes (Henderson, 1952). Bacteria could be maintained in this fluid at room temperature for over $\mathbf{3 0} \mathrm{min}$. without any change in colony count.

Radiochemicals. [U-14 C]-D-Glucose (3.9 mc/m-mole) was obtained from the Radiochemical Centre, Amersham, Buckinghamshire.

Measurement of radioactivity. The apparatus, methods and materials used for the determination of radioactivity by a 'coincidence counting' technique employing a liquid scintillator were as described by Anderson \& Smith (1965). Aqueous samples were generally mixed with an equal volume of formamide and stored in solid carbon dioxide until assayed.

Growth of organisms. For $\left[{ }^{14} \mathrm{C}\right]$-tracer studies the tryptone medium $(10 \mathrm{ml}$. containing [U-14 $\mathrm{C}$ ]-D-glucose (about $60 \mu \mathrm{g} . / \mathrm{ml}$.; $1.25 \mu \mathrm{C} / \mathrm{ml}$.) was inoculated (to $5 \times 10^{7}$ organisms $/ \mathrm{ml}$.) with a suspension of Escherichia coli then shaken (100 ml. flasks, $5 \mathrm{~cm}$. throw, 100 oscillations $/ \mathrm{min}$.) at $37^{\circ}$ for $16 \mathrm{hr}$. The bacteria were stored for $5 \mathrm{hr}$ at $4^{\circ}$ before use and contained about $30 \%$ of the original added tracer. Non-labelled bacteria were grown in a similar manner but in the absence of [U-14C]-D-glucose.

Where appropriate, $\beta$-galactosidase formation was induced in this organism by overnight growth in the liquid tryptone medium supplemented with iso-propylthio- $\beta$-D-galactopyranoside (0.10 m-mole/ml.; Rickenberg, Cohen, Buttin \& Monod, 1956). This substrate induced higher galactosidase values than did its thio-methyl analogue or lactose itself.

When dead $\left[{ }^{14} \mathrm{C}\right]$-labelled Escherichia coli was required as a tracer, a washed suspension of the organisms $\left(10^{10} \mathrm{bacteria} / \mathrm{ml}\right.$.) was shaken with $\left[\mathrm{U}-{ }^{14} \mathrm{C}\right]-\mathrm{D}$-glucose $\left(1.5 \mu \mathrm{C} / \mathrm{ml}\right.$.; $70 \mu \mathrm{g} . / \mathrm{ml}$.) in Locke's solution at $37^{\circ}$ for $30-60 \mathrm{~min}$. Following this 
treatment bacteria killed with formaldehyde $(4 \%, w / v ; 30 \mathrm{~min}$.) contained $30-60 \%$ of the original tracer after two washings with water.

Spores of Bacillus globigii produced after growth $\left(4\right.$ days, $\left.37^{\circ}\right)$ on peptone agar medium were washed off with water, heated $\left(60^{\circ} ; 2 \mathrm{hr}\right)$, stored $\left(4^{\circ}, 7\right.$ days $)$, reheated $\left(60^{\circ}, 2 \mathrm{hr}\right)$, then washed again and resuspended in water $\left(5 \times 10^{10} \mathrm{spores} / \mathrm{ml}\right.$. $)$. The spore suspension was stored at $4^{\circ}$ and renewed after 4 months; it was reheated $\left(60^{\circ}, 30 \mathrm{~min}\right.$. $)$ immediately before use to kill any vegetative organisms.

Determination of survival values. Viability was defined as the ability of an organism to produce a visible colony in $18 \mathrm{hr}$ at $37^{\circ}$ on the tryptone agar medium. Nonsprayed organisms were given a nominal viability of $100 \%$. Colony counts and radioactivity determinations were so arranged that the determined values of the viability estimates generally had a $95 \%$ confidence belt of $\pm 10 \%$.

Mixed suspensions of Escherichia coli and Bacillus globigii were assayed by differential colony counts on tryptone agar plates.

Total numbers of organisms recovered from aerosols were generally calculated from the observed radiotracer content of the recovered suspensions and from the radiotracer and colony count of non-aerosolized organisms. $\left[{ }^{14} \mathrm{C}\right]$-Labelled Escherichia coli was used to determine spore counts in studies with Bacillus globigii. B. globigii itself was used as a tracer of total bacterial numbers for comparative purposes only, in the few cases where the use of radiotracer was not possible.

Apparatus for the study of bacterial aerosols. Aerosols generated in a modified Collison atomizer were diluted with a stream of secondary air in a stainless steel mixing tube to give an atmosphere of the desired relative humidity (Henderson, 1952). The relative humidity of the aerosol could be adjusted over a range of from 35 to $100 \%$ by alteration of the water content of the secondary air. The characteristics of the Collison spray are such that a suspension containing 2 to $4 \times 10^{9}$ organisms $/ \mathrm{ml}$. yields an essentially monodisperse aerosol. Such a system was chosen to eliminate possible protective, or damaging, interactions between organisms in multicellular particles. The apparatus was adjusted to give flow rates of from $\mathbf{2 5}$ to $60 \mathrm{l}$./min. and aerosol concentrations up to $2 \times 10^{7}$ organisms $/$.

Aerosols emerging from the mixing tube were passed into a rotating stainless steel drum (75 l.) for storage. The construction and operation of the apparatus was similar to that described by Goldberg, Watkins, Boerke \& Chatigny (1958). The relative humidity of the atmosphere was determined by means of suitable conversion tables (Hodgman, 1948) from the observed differences between readings of 'wet and dry bulb' thermometers placed in the air stream. The temperature of the room containing the appartus was generally between $19^{\circ}$ and $22^{\circ}$ and did not vary by more than $\mathbf{0 . 2 ^ { \circ }}$ during experiments; the relative humidity of air leaving the apparatus seldom varied by more than $\pm 2 \%$.

Aerosol samples were generally collected for 45 sec. into phosphate buffer alginate (7-10 ml.) by using a sonic impinger with a throughput of $11 \mathrm{l} / \mathrm{min}$. (raised Porton impinger; May \& Harper, 1957).

\section{Preparation of suspensions for the generation of bacterial aerosols}

The method used in the preparation of suspensions of organisms for aerosolization depended on whether spores $(1),\left[{ }^{14} \mathrm{C}\right]$-labelled killed bacteria $(2)$, or $\left[{ }^{14} \mathrm{C}\right]$ labelled living bacteria (3), were to be used as indicator of total bacterial numbers. 
1. Bacillus globigii spores were heated, mixed with the labelled or unlabelled culture of Escherichia coli and the organisms separated from the culture fluids by centrifugation. The organisms were then washed once with water by centrifugation and resuspended in water (about $2 \times 10^{9}$ of each organism $/ \mathrm{ml}$.).

2. A mixture of equal numbers of organisms of a culture of Escherichia coli with $\left.{ }^{[14} \mathrm{C}\right]$-labelled formalized bacteria as tracer were treated exactly as the spore tracer for preparation of spray suspensions.

3. Suspensions of living $\left[{ }^{14} \mathrm{C}\right]$-labelled organisms could, however, be aerosolized directly after washing with water as above. This tracer method was used wherever possible to indicate total numbers of recovered populations.

Appropriate enzyme, colony counts and radioactivity determinations were made on suspensions before and after spraying to ensure that no change had taken place in populations during generation of the aerosol.

\section{Determination of the galactosidase content of pre-induced bacteria}

Samples of $\left[{ }^{14} \mathrm{C}\right]$-labelled induced organisms were collected and portions $(2 \mathrm{ml}$. containing 1 to $2 \times 10^{7}$ organisms in phosphate buffer alginate) were treated with a solution of substrate $(3 \mathrm{ml}$. of $2.5 \mathrm{mM}-0$-nitrophenol- $\beta$-D-galactopyranoside in $0.05 \mathrm{M}$ sodium phosphate buffer, $\mathrm{pH} 7 \cdot 2)$; benzene (0.1 ml.; Lederberg, 1950) and incubated at $37^{\circ}$ for $30 \mathrm{~min}$. Sodium carbonate solution $(1.0 \mathrm{M} ; 3 \mathrm{ml}$.) was then added and the mixture filtered (Whatman No. 1 paper) and the liberated 0 -nitrophenol determined colorimetrically at $420 \mathrm{~m} \mu$.

Samples of suspensions taken directly from the spray pot at the beginning and end of the experiment were diluted (1/500 in phosphate buffer alginate) and assayed in a similar manner. The organism hydrolysed about $5 \mu$ mole of 0 -nitrophenol- $\beta$-D-galactoside $/ 10^{10}$ bacteria/min.

\section{Determination of the ability of stressed organisms to produce galactosidase}

Samples of bacterial suspensions recovered from aerosols $\langle 4.5 \mathrm{ml}$. containing about $5 \times 10^{7}$ organisms in phosphate buffer alginate) were added to an inducer $(0.5 \mathrm{ml}$. of a $5 \mathrm{~mm}$-solution of methyl-thio- $\beta$-D-galactopyranoside; Lederberg, 1950) in tryptone medium, and gently rotated in a tube at $37^{\circ}$ for $30 \mathrm{~min}$. The presence of this small quantity of growth medium enhanced galactosidase production. Diluted suspensions (1/500 or 1/1000 in phosphate buffer alginate) of samples removed from the spray pot at the beginning and end of the experiment were treated similarly. The induced bacteria were then treated with substrate $(0.5 \mathrm{ml}$. of a $15 \mathrm{~mm}$-solution of 0 -nitrophenol- $\beta$-D-galactopyranoside in $0.05 \mathrm{M}$-sodium phosphate buffer, $\mathrm{pH} 7 \cdot 2)$ and benzene $\left(0 \cdot 1 \mathrm{ml}\right.$.). After incubation at $37^{\circ}$ for $30 \mathrm{~min}$. the $o$-nitrophenol content was determined as above.

\section{RESULTS}

\section{Development of a radiotracer technique for estimating total numbers of organisms in recovered aerosols}

Spores of Bacillus globigii have been used as a tracer for determining total numbers in bacterial aerosols despite doubts about the stability of this organism (Harper, Hood \& Morton, 1958; Cox, 1966). In initial studies with this tracer 
apparent viabilities of up to $160 \%$ of those of unsprayed organisms were obtained when populations of Escherichia coli were recovered from recently generated aerosols. These high apparent viabilities might have been caused by division or disaggregation of $\boldsymbol{E}$. coli or death of $\boldsymbol{B}$. globigii. No change in numbers was detected in suspensions of $B$. globigii or $E$. coli remaining in the spray pot at the end of experiments in which these organisms would have re-circulated 50 times through the jets of the spray. The use of $\left[{ }^{14} \mathrm{C}\right]$-labelled $E$. coli was therefore introduced to investigate the suspected death of $\boldsymbol{B}$. globigii in the aerosol and to provide a tracer for biochemical work where the presence of another organism would invalidate results.

Table 1. Evidence for the biological similarity of aerosols of $\left[{ }^{14} \mathrm{C}\right]$-labelled and non-labelled Escherichia coli

\begin{tabular}{|c|c|c|c|c|}
\hline & \multicolumn{2}{|c|}{ Relative humidity $=53 \%$} & \multicolumn{2}{|c|}{ Relative humidity $=88 \%$} \\
\hline $\begin{array}{l}\text { Age of } \\
\text { aerosol } \\
\text { cloud }\end{array}$ & $\begin{array}{c}\text { Viability }(\%) \\
\text { of } \\
\left.\text { [ }{ }^{14} \mathrm{C}\right]- \text {-labelled } \\
\text { E. coli } \\
\text { (Bacillus } \\
\text { globigii } \\
\text { tracer) }\end{array}$ & $\begin{array}{c}\text { Viability }(\%) \\
\text { of } \\
\text { non-labelled } \\
\text { E. coli } \\
\text { (Bacillus } \\
\text { globigii } \\
\text { tracer) }\end{array}$ & $\begin{array}{c}\text { Viability }(\%) \\
\text { of } \\
E . \text { coli } \\
\text { labelled } \\
\text { internally } \\
\text { with }\left[{ }^{14} \mathrm{C}\right]\end{array}$ & $\begin{array}{c}\text { Viability }(\%) \\
\text { of } \\
\text { non-labelled } \\
E . \text { coli } \\
\text { with external } \\
{\left[{ }^{14} \mathrm{C}\right] \text {-tracer }}\end{array}$ \\
\hline $\begin{array}{l}\text { unsprayed } \\
\text { control }\end{array}$ & $(100)$ & $(\mathbf{1 0 0 )}$ & (100) & (100) \\
\hline $1 \cdot 2 \mathrm{sec}$ & 78 & 77 & 73 & 75 \\
\hline 2 min. & 43 & 45 & $\mathbf{5 2}$ & 57 \\
\hline $10 \mathrm{~min}$. & 32 & 38 & 9 & 9 \\
\hline 30 min. & 16 & 19 & 3 & 5 \\
\hline
\end{tabular}

Before using [ $\left.{ }^{14} \mathrm{C}\right]$-labelled Escherichia coli as a tracer for total bacterial numbers the possibility of damage by radioactivity had to be eliminated, since the organisms were grown and stored in the presence of radioisotope and might be particularly sensitive to radiation in the aerosol. Comparison of the viability of recovered aerosols of [ $\left.{ }^{14} \mathrm{C}\right]$-labelled and non-labelled $E$. coli, using Bacillus globigii as a tracer, indicated that the radioisotope was not harmful (Table 1). This comparison was carried out under identical conditions with the same batch of spore tracer to minimize the effects of death of the spore. Similar results were obtained when $\left[{ }^{14} \mathrm{C}\right]-$ labelled $\boldsymbol{E}$. coli was compared with the non-labelled bacteria using dead $\left[{ }^{14} \mathrm{C}\right]-$ labelled organisms as an external tracer (Table 1). An external tracer was used to test the possibility that, if radiation damage only occurred in the aerosol, the spatial separation of radioisotope from the living organism and consequent diminished radiation flux might result in a measurable difference in viability. The external $\left[{ }^{14} \mathrm{C}\right]$-tracer also confirmed the results obtained with the spore tracer. Further proof of the biological similarity of $\left[{ }^{12} \mathrm{C}\right]$ - and $\left[{ }^{14} \mathrm{C}\right]$-organisms was provided by comparison of the effect of heat stress (Table 2). Finally, the viable count of cultures of $\left[{ }^{12} \mathrm{C}\right]-$ and $\left[{ }^{14} \mathrm{C}\right]$-organisms were shown to be similar, and to remain so during storage at $4^{\circ}$ for up to 1 week.

Application of the radiotracer technique to mixed suspensions of $\left[{ }^{14} \mathrm{C}\right]$-labelled Escherichia coli (as a tracer for the spore tracer) and Bacillus globigii spores showed that there was, initially, a rapid death of the spore tracer. Viability determinations 
on spores recovered from aerosols 1.2 sec. after generation, at 37 points, at relative humidities ranging from 40 to $97 \%$ suggest that the initial decrease in viability tended to increase with increasing relative humidity (correlation coefficient $=$ $-0.34 ; \boldsymbol{P}=$ approximately $4 \%$ ). The regression of viability $\%(V)$ on relative humidity $\%(H)$ gave the equation $V=87 \cdot 9-0.267 H$ with $95 \%$ fiducial limits of $\pm \mathbf{2 8} \%$ (approximately over the relevant range). From the wide range of the fiducial limits of this equation the reproducibility was obviously unsatisfactory. The lethal effect on a proportion of the population appeared to be almost instantaneous, with no evidence of further change at up to $30 \mathrm{~min}$. (Table 3). The use of this spore was therefore discontinued. The viability of spore suspensions remained unchanged on agitation in an impinger for up to $3 \mathrm{~min}$. Death of the spore during impingement found under different experimental conditions by Levine \& Cabelli, (1963) can therefore be discounted.

Table 2. Evidence for the biological similarity of $\left[{ }^{14} \mathrm{C}\right]$-labelled and non-labelled organisms of Escherichia coli during exposure to heat stress

$10^{7} \mathrm{E}$. coli $/ \mathrm{ml}$. in phosphate buffer alginate; nominal viability of non-stressed organisms $=100 \%$

$$
\begin{aligned}
& \text { Period of } \\
& \text { stress } \\
& \text { (min.) }
\end{aligned}
$$

15

30

45

Viability
$(\%)$ of
non-labelled
organisms

108

79

7

51

11

28

8
Viability

(\%) of

$\left[{ }^{14} \mathrm{C}\right]$-labelled

organisms

101

77

5

57

11

0

31

6

\begin{tabular}{|c|c|c|}
\hline \multirow[b]{2}{*}{$\begin{array}{c}\text { Age of } \\
\text { aerosol cloud }\end{array}$} & \multicolumn{2}{|c|}{$\begin{array}{l}\text { Viability (\%) of } \\
\text { Bacillus globigii }\end{array}$} \\
\hline & $\begin{array}{c}\text { At a } \\
\text { relative } \\
\text { humidity } \\
\text { of } 54 \%\end{array}$ & $\begin{array}{c}\text { At a } \\
\text { relative } \\
\text { humidity } \\
\text { of } 94 \%\end{array}$ \\
\hline $\left.\begin{array}{c}\text { unsprayed } \\
\text { suspension }\end{array}\right\}$ & (100) & $(100)$ \\
\hline $1 \cdot 2$ sec. & 72 & 77 \\
\hline 5 min. & 75 & 82 \\
\hline $10 \mathrm{~min}$. & 71 & 86 \\
\hline 20 min. & 75 & 74 \\
\hline 30 min. & 84 & 69 \\
\hline
\end{tabular}

Table 3. Evidence for the absence of any significant decrease in the viability of recovered aerosols of Bacillus globigii after the initial rapid death

\section{Measurement of the effect of relative humidity and holding time on aerosols of Escherichia coli}

Figure 1 shows the effect of a range of twenty-seven relative humidity values on the viability of aerosolized populations of Escherichia coli. To simplify the graphical 
representation, data have only been presented for bacterial clouds recovered at 1.2 sec., 5 min. and 30 min., although samples had also been taken at 10 and $20 \mathrm{~min}$. These figures suggest that there were zones of relative humidity where the viability of the bacterial populations decreased rapidly. Figure 2 represents graphically 3 of the $27 \mathrm{log}$ viability-time curves which illustrate the typical initial rapid decay of the organism, followed by a slower decay which was reasonably linear in the range 5-30 min. The dot diagram (Fig. 3) of these twenty-seven regression coefficients against relative humidity suggests that after the initial rapid decay the death rate is minimum at about $80 \%$ and rises rapidly at higher humidities.

\section{Measurement of the stability of cell protein following generation and recovery of aerosols of Escherchia coli}

Bacterial death in organisms recovered from aerosols might be due to damage to cell proteins. To test this $\beta$-galactosidase was chosen as a model protein, since a

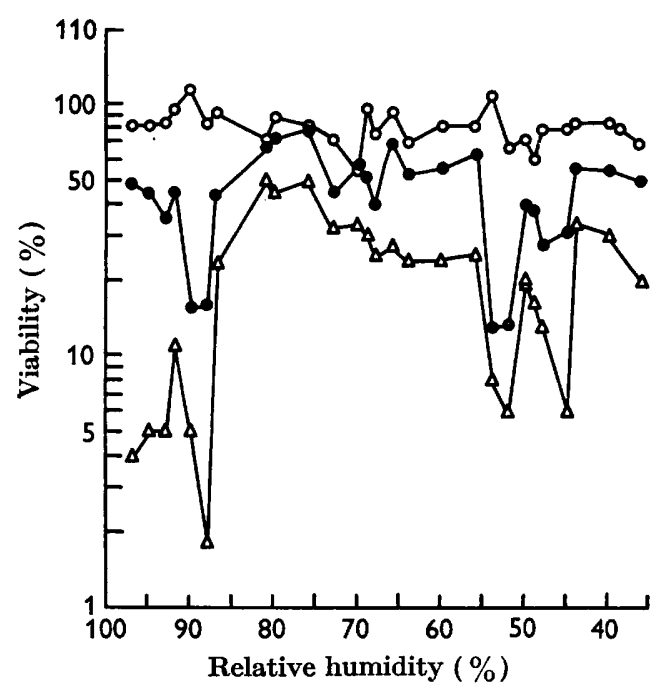

Fig. 1

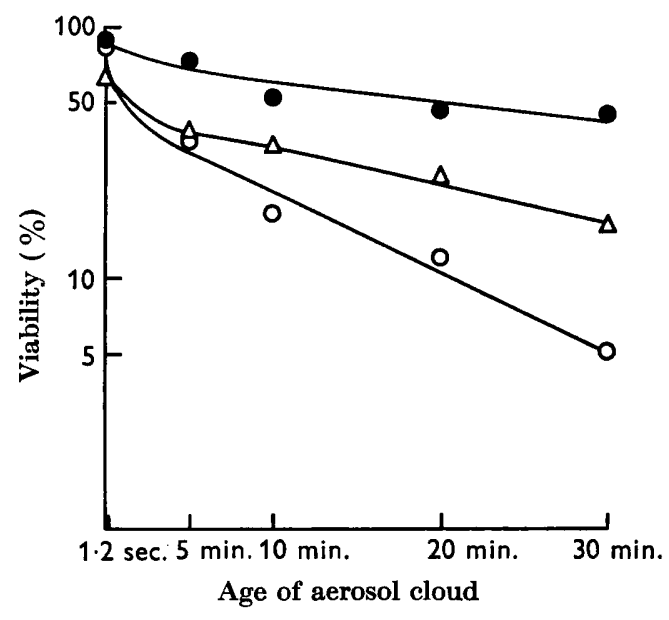

Fig. 2

Fig. 1. Viability of populations of Escherichia coli, strain B, recovered from aerosols $1.2 \mathrm{sec}(-\mathrm{O}-\mathrm{O}-), 5 \mathrm{~min}$. (- - - ) and $30 \mathrm{~min} .(-\Delta-\Delta-)$ after generation.

Fig. 2. Viability of populations of Escherichia coli, strain $\mathrm{B}$, held at relative humidities of $80 \%(-\bigcirc-), 49 \%(-\triangle-\triangle-)$ and $93 \%(-\mathrm{O}-\mathrm{O}-)$ at intervals up to $30 \mathrm{~min}$.

convenient sensitive assay method was available, and its enzymic activity could be used as a criterion of structural integrity. $\beta$-Galactosidase formation was induced in Escherichia coli by growth in a medium containing iso-propyl-thio- $\beta$-D-galactopyranoside. The general properties and death rate on aerosolization of the induced $\boldsymbol{E}$. coli were similar to those of similar bacteria grown without an inducer. The specific activity of the $\beta$-galactosidase, in populations recovered from aerosols, was determined and expressed as a percentage of that in unsprayed organisms. Table 4 summarizes results obtained with bacterial clouds sampled at the longest time after generation ( $30 \mathrm{~min}$.) when damage to $\beta$-galactosidase would be expected to be greatest. Aerosolization had little effect on the specific $\beta$-galactosidase activity of 
Table 4. Changes in the $\beta$-galactosidase value and viability of pre-induced organisms of Escherichia coli recovered from aerosol clouds held at various relative humidities for 30 min.

\begin{tabular}{lrrrrrrrrrr|} 
Relative humidity: & 42 & 51 & 58 & 68 & 68 & 77 & 84 & 90 & 94 & 99 \\
$\beta$-Galactosidase level*: & 104 & 108 & 130 & 120 & 102 & 91 & 106 & 101 & 97 & 126 \\
Viability*: & 19 & 13 & 42 & 56 & 44 & 12 & 12 & 9 & 1 & 6
\end{tabular}

* The nominal specific activity (enzyme/total no. bacteria) of the $\beta$-galactosidase of nonaerosolized organisms $=100 \%$. The nominal viability of these organisms $=100 \%$.

$E$. coli despite large changes in viability; this was true at various relative humidities and different holding times. Combined results of all 10 experiments for samples removed at aerosol ages of $1.2 \mathrm{sec} ., 5 \mathrm{~min} ., 10 \mathrm{~min} ., 20 \mathrm{~min}$. and $30 \mathrm{~min}$. strongly indicate a small positive regression (significance level being $0.001 \%$ ) in the plot of

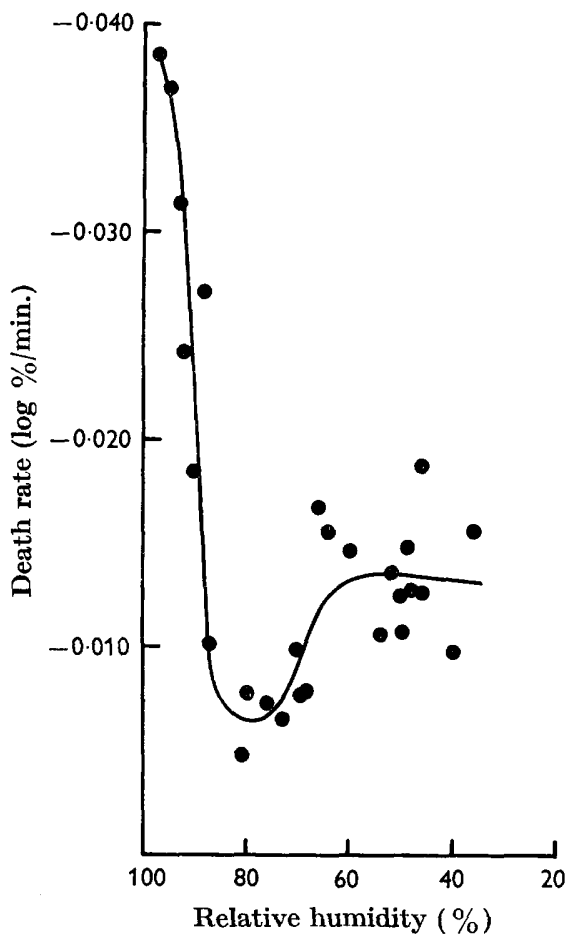

Fig. 3

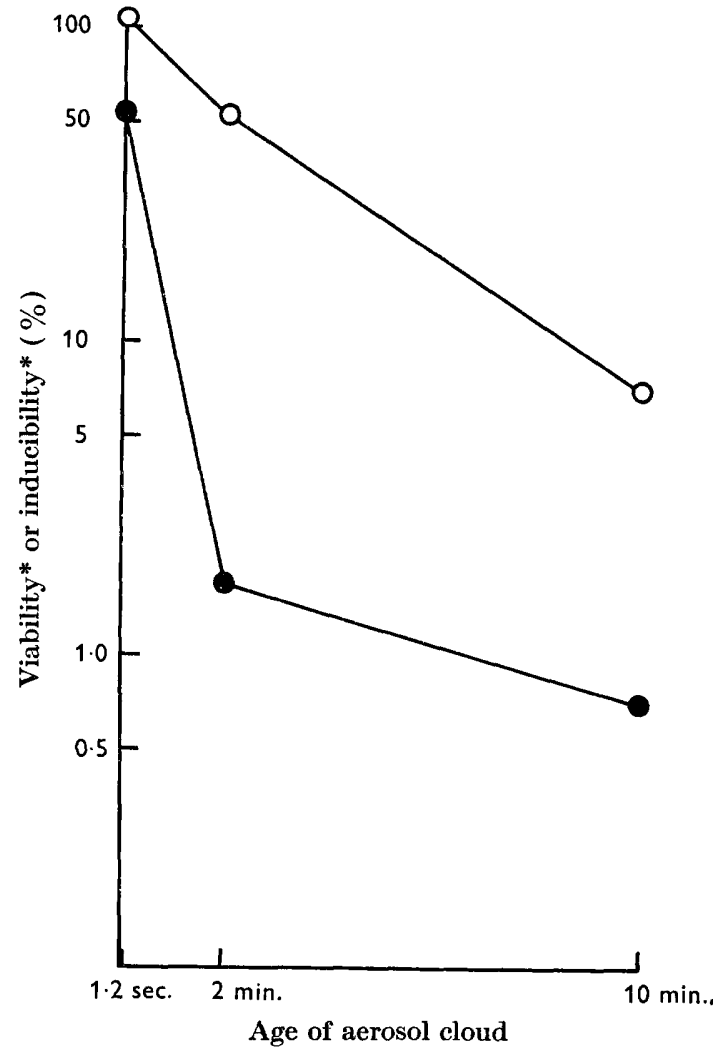

Fig. 4

Fig. 3. The effect of relative humidity on the death rate (over the period $5-30 \mathrm{~min}$.) of populations recovered from aerosols of Escherichia coli, strain $\mathbf{B}$.

Fig. 4. The viability (-O-O- $)$ and induced galactosidase (- - - - ) levels of organisms of Escherichia coli strain B, recovered from an aerosol cloud held at a relative humidity of $91 \%$ * For unsprayed organisms the nominal galactosidase activity resulting from induction in a standard test $=100 \%$ and the nominal viability $=100 \%$. 
galactosidase activity against holding time, amounting to only $5 \%$ over $30 \mathrm{~min}$. Although statistically significant this change is trivial and might be an artifact caused by the increased accessibility of the enzyme to the test substrate in the thoroughly dried bacteria. Combined results also gave a non-significant $(P=11 \%)$ regression in the plot of galactosidase activity against relative humidity.

Ability of Escherichia coli to synthesize protein following recovery from aerosols

Damage to protein synthesizing mechanisms might be lethal in organisms recovered from aerosols. The importance of such damage could be assessed if a relationship could be established between the relative extent of changes of viability and changes in the ability of organisms recovered from aerosols to synthesize protein in response to a specific stimulus. $\beta$-Galactosidase was again chosen as a model protein and a $\beta$-galactosidase inducer as the stimulus. The ability of Escherichia coli to synthesize $\beta$-galactosidase immediately after recovery from aerosols decreased so rapidly with increasing aerosol age that the induced enzyme value proved too low to measure on organisms recovered from bacterial clouds more than 10 min. after generation. Fig. 4 illustrates the results of one typical experiment. Table 5 summarizes the results of 13 experiments and gives some evidence that induced galactosidase values decreased relatively faster than viability as the holding time in the aerosol increased. This decrease was obvious between 0 and 1.2 sec. and between $1.2 \mathrm{sec}$. and $2 \mathrm{~min}$. Unfortunately the confidence belt of the $10 \mathrm{~min}$. data $(0 \cdot 14)$ was widened by an anomalous result for one of the thirteen observations where the induced galactosidase value was relatively greater than the viability.

Table 5. Summary of evidence for a correlation between changes in the ability of Escherichia coli to synthesize $\beta$-galactosidase immediately after recovery from aerosols and changes in viability

\begin{tabular}{|c|c|}
\hline $\begin{array}{c}\text { Age of } \\
\text { aerosal cloud }\end{array}$ & $\begin{array}{l}\text { *Induced galactosidase value } \\
\text { viability } \\
\text { Mean (95\% fiducial limits) }\end{array}$ \\
\hline $1 \cdot 2$ sec. & $0.59(0.43-0.79)$ \\
\hline 2 min. & $0.30(0 \cdot 22-0 \cdot 40)$ \\
\hline 10 min. & $0.14(0.04-0.51)$ \\
\hline
\end{tabular}

* Mean of 13 determinations at relative humidities from 49 to $99 \%$. For non-aerosolized organisms the nominal galactosidase activity resulting from induction in a standard test $=100 \%$, and the nominal viability $=100 \%$.

\section{DISCUSSION}

Total bacterial numbers in biological aerosols have been estimated by methods involving dyes (e.g. Dunklin \& Puck, 1948; Henderson, 1952; Wolfe, 1961), radiophosphorus (Harper \& Morton, 1952; Harper et al. 1958), radiosulphur (Miller, Scherff, Prepoli \& Idoine, 1961), spores (Harper et al. 1958) and photoelectric measurements (e.g. Fisher, Katz, Lieberman \& Alexander, 1955; Ferry, Brown \& Damon, 1958). The $\left[{ }^{14} \mathrm{C}\right]$-tracer technique has the advantage over these methods that a stable and easily determined tracer was incorporated within the bacteria which were actually being studied, without appreciably altering either medium, growth condition or spray fluid. The instability of Bacillus globigii spores was unexpected since their resistance to other stresses, including storage in various 
environments, and to heat, is well known. No explanation can be offered for the anomalous behaviour of these spores.

Most of the work described in this paper was concerned with recovered aerosols having viabilities of from 5 to $\mathbf{1 0 0} \%$. Populations of lower viability were avoided since death processes in highly stressed, and thus perhaps, selected, organisms might not be representative of those causing death of the bulk of a population in the aerosol. The plot of log survival versus time for bacterial aerosols may commonly be divided into two or more distinct regions. The death rate of Escherichia coli strain B, under the conditions described here, can be represented by an initial ( $0-5 \mathrm{~min}$.) rapid decay followed by a slower logarithmic decay over 5-30 min. Data for the survival of organisms recovered from aerosols $5 \mathrm{~min}$. after generation provide a measure of the initial rapid decay and demonstrate the appearance of troughs in the plot of survival versus relative humidity (Fig. 1). Comparatively narrow zones of relative humidity at which dried bacteria are unstable have been found in other experimental systems, e.g. freeze-dried organisms of Serratia marcescens die most rapidly at a water content corresponding to equilibration with water vapour at a relative humidity of approximately $90 \%$ (Monk, Elbert, Stevens \& McCaffrey, 1956; Monk \& McCaffrey, 1957; Bateman, McCaffrey, O'Connor \& Monk, 1961). Davis \& Bateman (1960) observed a similar phenomenon with freeze-dried, washed suspensions of $\boldsymbol{E}$. coli. Aerosols of several strains of $\boldsymbol{E}$. coli display sharp troughs in the plot of survival versus relative humidity in an atmosphere of nitrogen (Cox, 1966); for $E$. coli strain B these troughs occurred at relative humidities of 100,97 , 85 and $50 \%$.

The dependence of the later (5-30 min.) phase of decay upon relative humidity (Fig. 3) is quite different from the initial decay process. The completely different responses of the processes represented by the two parts of the decay curve to changes of relative humidity suggests that at least two sequential lethal processes occur.

Experimental difficulties inherent in the study of the small populations which may be recovered from bacterial aerosols may be avoided when bacterial suspensions are dried on filter membranes to simulate the aerosolized state. Webb and colleagues (see review by Webb, 1965) studied the effect of drying on several biochemical systems in bacteria by using such membranes. However, lethal processes in the aerosol may not parallel those on membrane filters, since death and dehydration rates of bacteria on filter membranes are generally much lower than in aerosols. Also, bacteria on a membrane filter are not subject to mechanical stresses as in an aerosol and are in contact with a solid surface, in contrast to the aerosol environment. Nevertheless, the present results with $\beta$-galactosidase stability and induction in aerosolized bacteria are in general agreement with Webb's (1965) findings.

If $\beta$-galactosidase is typical of bacterial proteins then although there is no extensive destruction of the protein itself in the aerosol or immediately after recovery, loss of protein-synthesizing ability either leads to death or is an expression of the lethal lesion. Since organisms recovered from aerosol clouds $\mathbf{1 . 2}$ sec. after generation of the aerosol are substantially viable (70-100\%) yet show a severe decrease in their ability to synthesize protein in response to a specific stimulus, this decrease must either be reversible or not immediately lethal. Study of protein synthesis in 
organisms immediately after recovery from aerosols might indicate the site of the actual lethal process.

I am most grateful to Mr I. H. Silver for his encouragement and suggestions during the course of this work, to Mr R. E. Strange for helpful discussions, to Mr S. Peto for statistical analysis and advice and to Mr G. Crouch for technical assistance.

\section{REFERENCES}

Anderson, J. D. \& Smith, H. (1965). The metabolism of erythritol by Brucella abortus. J. gen. Microbiol. 38, 109.

Bateman, J. B., McCaffrey, P. A., O'Connor, R. J. \& Monk, G. W. (1961). Relative humidity and the killing of bacteria. The survival of damp Serratia marcescens in air. Appl. Microbiol. 9, 567.

Cox, C. S. (1966). The survival of Escherichia coli atomized into air and into nitrogen from distilled water and from solutions of protecting agents as a function of relative humidity. J. gen. Microbiol. 43, 383.

Davis, M. S. \& Bateman, J. B. (1960). Relative humidity and the killing of bacteria. J. Bact. 80, 577 .

Dunklin, E. W. \& Puck, T. T. (1948). The lethal effects of relative humidity on airborne bacteria. J. exp. Med. 87, 87.

Ferry, R. M., Brown, W. F. \& Damon, E. B. (1958). Studies of the loss of viability of stored bacterial aerosols. J. Hyg. Camb. 56, 125.

Fisher, M. A., Katz, S., Lieberman, A. \& Alexander, N. E. (1955). The aeroloscope: an instrument for the automatic counting and sizing of aerosol particles. Proceedings National Air Pollution Symposium Pasadena, California, p. 112.

Goldberg, L. J., Watkins, H. M. S., Boerke, E. E. \& Chatigny, M. A. (1958). The use of a rotating drum for the study of aerosols over extended periods of time. Am. J. Hyg. 68,85 .

Goodlow, R. J. \& LeONARD, F. A. (1961). Viability and infectivity of microorganisms in experimental airborne infection. Bact. Rev. 25, 182.

Harper, G. J. \& Morton, J. D. (1952). Bacillus subtilis spores labelled with radiophosphorus. J. gen. Microbiol. 7, 98.

Harper, G. J., Hood, A. M. \& Morton, J. D. (1958). Airborne microorganisms : technique for studying their survival. J. Hyg. Camb. 56, 364.

Henderson, D. W. (1952). An apparatus for the study of airborne infection. J. Hyg., Camb. 50, 53.

Hodgman, C. D. (1948). Handbook of Chemistry and Physics, 30th ed. Cleveland, Ohio: Chemical Rubber Publishing Co. 1922.

LeDerberg, J. (1950). The $\beta$-D-galactosidase of Escherichia coli, strain K12. J. Bact. $60,381$.

Levine, M. A. \& Cabelli, V. J. (1963). Germination of spores as a consequence of aerosolization and collection. Bact. Proc. 26.

MAY, K. R. \& HARPER, G. J. (1957). The efficiency of various liquid impinger samplers in bacterial aerosols. Br. J. ind. Med. 14, 287.

Miluer, W. S., Scherff, R. A., Piepoli, C. R. \& Idoine, L. S. (1961). Physical tracers for bacterial aerosols. App. Microbiol. 9, 248.

Monk, G. W. \& MCCAFFrEy, P. A. (1957). Effect of sorbed water on the death rate of washed Serratia marcescens. J. Bact. 73, 85.

Monk, G. W., Elbert, M. L., Stevens, C. L. \& McCaffrey, P. A. (1956). The effect of water on the death rate of Serratia marcescens. J. Bact. 72, 368.

Rickenberg, H. V., Cohen, G. N., Buttin, G. \& Monod, J. (1956). La galactoside-permease d'Escherichia coli. Ann. Inst. Pasteur 91, 829.

WEBB, S. J. (1965). Bound Water in Biological Integrity. Springfield, Illinois: Charles C. Thomas.

WoLFE, E. K. (1961). Quantitative characteristics of aerosols. Bact. Rev. 25, 194. 